\title{
Pengaruh Home Visit terhadap Penurunan Episode Penyakit Infeksi dan Peningkatan Angka Kecukupan Gizi pada Balita Malnutrisi Akut Berat
}

Titih Huriah

\author{
Program Magister IImu Keperawatan, Program Pasca Sarjana \\ Universitas Muhammadiyah Yogyakarta Kampus Terpadu UMY \\ JI. Ringroad Selatan Tamantirto Kasihan Bantul Yogyakarta \\ Email: titih.huriah@umy.ac.id / titih_psikumy@yahoo.com
}

\begin{abstract}
Malnutrisi akut berat merupakan salahsatu bentuk malnutrisi yang paling mempengaruhi balita dan hal ini berkaitan dengan penyakit infeksi dan asupan nutrisi. Saat ini penanganan malnutrisi pada balita lebih dikembangkan dengan pendekatan berbasis komunitas, salahsatunya adalah program home visit. Tujuan pada penelitian ini adalah untuk mengetahui pengaruh home visit dalam menurunkan episode penyakit infeksi dan meningkatkan asupan nutrisi pada balita dengan malnutrisi akut berat usia 6-60 bulan. Desain penelitian menggunakan kuasi eksperimen dengan rancangan pretest-posttest control group design. Lokasi penelitian dilakukan di 32 puskesmas di Provinsi Yogyakarta. 56 balita dengan diagnosis malnutrisi akut berat diseleksi menggunakan purposive sampling. Penelitian dilaksanakan dengan menggunakan 3 fase pendekatan yaitu fase intensif, penguatan, dan fase mandiri melalui pemberan asuhan keperawatan. Data analisis menggunakan software SPSS. Hasil penelitian menunjukkan nilai rerata episode penyakit infeksi sebelum diberikan home visit adalah 2,64 hari dan setelah pemberian home visit menjadi 0,21 hari. Keadekuatan asupan nutrisi sebelum diberikan intervensi hanya mencapai 83,65\% dan setelah intervensi mencapai 106,23\%. Setelah pemberian intervensi home visit selama 3 bulan, terdapat penurunan episode penyakit infeksi dan peningkatan asupan nutrisi yang signifikan dengan nilai p-value 0,0003 dan 0,003.
\end{abstract}

Abstrak

Kata Kunci: malnutirisi akut berat, balita, home visit, episode penyakit infeksi, asupan nutrisi

\section{The Effect of Home Visit on Decreasing Episodes of Infectious Diseases and Increase Recomended Dietary Allowance in Underweight Children with Severe Acute Malnutrition}

\begin{abstract}
Severe Acute Malnutrition (SAM) is the most serious form of malnutrition affecting children under-five and is associated with many infectious diseases and nutrition intake. Today, the management of acute malnutrition is developed in community based, and home visit program is the form of community based program. The purpose of this study was to evaluate effect of home visit intervention in decreasing infectious diseases episode and increasing nutrition intake of severe acute malnutrition children aged 6-60 months. Quasi-experimental with pretest-posttest control group design was carried out for this study. The study was done in two district involving 32 health centers of Yogyakarta province. 56 children with SAM were selected using purposive sampling. The study was performed in three phases, intensive, strengthening and independent phase applying nursing care approach. Data analysis was done by SPSS software. Mean episodes of infectious diseases in the baseline at home visit group was 2,64 days and after the intervention the mean was 0,21 days. Nutritional adequacy rate in the baseline only reached $83,65 \%$ and after intervention reached 106,23\%. During the three months intervention of home visit, there were significant decreases in infectious diseases episode and increases nutrition intake with p-value 0,0003 and 0,003 respectively.
\end{abstract}

Keywords: severe acute malnutrition, children, home visit, infectious diseases episode, nutrition intake

Info Artikel:

Artikel dikirim pada 10 Februari 2017

Artikel diterima pada 27 Maret 2017

DOI : http://dx.doi.org/10.21927/jnki.2017.5(1).33-41 


\section{PENDAHULUAN}

Malnutrisi masih merupakan masalah utama pada anak balita. Lebih dari 77 juta anak lahir setiap tahun di 36 negara dengan angka kejadian malnutrisi yang tinggi (21 negara di Afrika, 13 di Asia dan 2 negara di Amerika Latin) (1-3). Secara global, diperkirakan 130 juta anak balita mengalami malnutrisi dan merupakan resiko yang berhubungan dengan angka kematian dan kesakitan balita $(2,4,5)$. Prevalensi status gizi balita berdasarkan Berat Badan per Tinggi Badan (BB/TB) di Daerah Istimewa Yogyakarta menunjukkan prevalensi status gizi balita sangat kurus 2,6\% dan kurus 6,5\% (6). Kekurangan nutrisi pada balita merupakan masalah yang serius di negara berkembang, yang berdampak pada tumbuh kembang balita dan berkontribusi pada setengah dari kematian anak balita $(2,7)$. Malnutrisi akut berat terdiagnosis dengan adanya edema, sering mengalami penyakit infeksi, kekurangan nutrisi, dan merupakan penyebab dari satu sampai dua juta anak meninggal setiap tahun (7).

Malnutrisi dapat disebabkan dari ketidakadekuatan makanan atau dapat disebabkan karena penyakit atau kecacatan (8). Terdapat 2 faktor penyebab dari gizi buruk yaitu penyebab langsung dan penyebab tidak langsung. Penyebab langsung yaitu kurangnya jumlah dan kualitas makanan yang dikonsumsi dan menderita penyakit infeksi. Penyebab tidak langsung yaitu ketersediaan pangan rumah tangga, perilaku, pelayanan kesehatan $(9,10)$.

Faktor penyebab langsung malnutrisi adalah konsumsi makanan yang tidak memenuhi jumlah dan komposisi zat gizi yang memenuhi syarat makanan beragam, bergizi seimbang, dan aman. Asupan makanan yang tidak adekuat dapat berkontribusi pada tingginya angka malnutrisi pada balita (11). Ketersediaan pangan pada tingkat rumah tangga mempengaruhi konsumsi makanan individu dan keluarga.

Faktor penyebab langsung malnutrisi yang kedua adalah penyakit infeksi. Malnutrisi dan infeksi dapat dilihat dari dua aspek dimana malnutrisi menyebabkan penurunan daya tahan tubuh seseorang dan infeksi menyebabkan malnutrisi melalui patogenesis penyakit. Hubungan malnutrisi dengan penyakit infeksi juga dapat dilihat secara level mikro dan makro. Pada level mikro yaitu dari sisi individu, dimana tingkat imunitas seseorang dipengaruhi oleh asupan makronutrien dan mikronutrien yang optimal sehingga terjadi malnutrisi dan menurunkan respon imun $(12,13)$.
Malnutrisi dan penyakit infeksi merupakan hubungan saling mempengaruhi secara langsung (bidirectional), dimana malnutrisi dapat menyebabkan penyakit infeksi dan infeksi dapat mengganggu metabolisme zat gizi sehingga menyebabkan malnutrisi (12).

Perkembangan saat ini, penanganan balita dengan malnutrisi baik malnutrisi akut maupun malnutrisi kronik lebih dikembangkan dengan berbasis komunitas. Penanganan berbasis komunitas terdiri dari tiga pendekatan yaitu program intervensi di masyarakat, home based treatment untuk balita malnutrisi tanpa komplikasi, dan pusat stabilisasi untuk balita malnutrisi dengan komplikasi. Home based treatment atau home visit merupakan salahsatu pendekatan yang masih jarang dilakukan di Indonesia khususnya di Yogyakarta. Penelitian ini bertujuan untuk mengetahui pengaruh home visit terhadap penurunan episode penyakit infeksi dan peningkatan asupan nutrisi pada balita malnutrisi akut berat.

\section{BAHAN DAN METODE}

Desain penelitian yang digunakan adalah kuasi eksperimen dengan pendekatan pre-test post-test with control group. Populasi penelitian adalah semua balita usia 6-60 bulan yang terdiagnosis malnutrisi akut berat di dua Kabupaten di Yogyakarta yaitu balita di Kota Yogyakarta sebagai kelompok intervensi dan balita di Kabupaten Sleman sebagai kelompok kontrol. Sampel adalah semua balita malnutrisi akut berat yang berjumlah 56 balita dengan pembagian 33 balita di Kota Yogyakarta dan 23 balita malnutrisi akut berat di Kabupaten Sleman. Kriteria inklusi yang diterapkan yaitu populasi balita malnutrisi akut berat tanpa atau malnutrisi akut dengan komplikasi yang dirawat di rumah atau setelah perawatan di rumah sakit (fase rehabilitasi) namun masih menderita malnutrisi. Kriteria balita malnutrisi akut berat tanpa komplikasi adalah BB/PB atau BB/TB: <-3 SD Z Score. Kriteria balita malnutrisi akut dengan komplikasi adalah $\mathrm{BB} /$ PB atau BB/TB: <-2 SD Z Score. Kriteria eksklusi pada penelitian ini adalah balita malnutrisi sedang yang jatuh pada kondisi malnutrisi berat yang harus dirawat di Rumah Sakit sesuai dengan protokol dari WHO yaitu dengan kriteria terdapat bilateral pitting edema, dan terdapat satu gejala ini: ISPA, demam tinggi, anemia berat, dan tidak sadar. Intervensi yang diberikan adalah home visit sedangkan pada kelompok kontrol mendapatkan intervensi standar yaitu Pemberian Makanan Tambahan-Pemulihan (PMT-P). Analisis yang digunakan adalah WHO 
anthro untuk menganalisis pengukuran antropometri untuk indikator BB/TB. Analisis data menggunakan uji deskriptif, kai kuadrat, independent-t test, dan regresi logistik.

Alat yang digunakan untuk mengukur berat badan adalah timbangan berat badan digital yang telah dikalibrasi dengan kapasitas $150 \mathrm{~kg}$ dan ketelitian 50 gram; menggunakan baterai $3 \mathrm{~A}$ sebanyak 2 buah. Pengukuran tinggi badan pada responden kurang dari 2 tahun dilakukan pengukuran panjang badan dengan menggunakan Length measuring dalam posisi tidur. Pengukuran tinggi badan pada responden $\geq 2$ tahun dilakukan dalam posisi berdiri dengan menggunakan Microtoise dengan kapasitas ukur 2 meter dan ketelitian $0,1 \mathrm{~cm}$. Timbangan digital telah dikalibrasi sebelum pelaksanaan penelitian. Malnutrisi akut berat diukur dengan menggunakan indikator BB/TB atau $\mathrm{BB} / \mathrm{PB}$ (wasted) dengan kategori $<70 \%$ nilai median $\mathrm{BB} / \mathrm{TB}$ atau $\mathrm{z}$ score $<-3 \mathrm{SD}$ dan malnutrisi akut dengan komplikasi ( $<80 \%$ nilai median BB/TB atau $<-2 \mathrm{SD}$ ).

Episode penyakit infeksi diukur dengan cara menghitung jumlah hari sakit dua minggu pertama intervensi dan dua minggu sebelum intervensi home visit berakhir. Batasan ISPA adalah gejala demam, batuk, beringus dan sesak napas. Batasan diare adalah berak cair $\geq 3$ kali dalam sehari. Angka kecukupan gizi diukur dengan menilai perbandingan persentase rata-rata angka kecukupan energi yang diukur dua hari minggu pertama intervensi dan dua hari terakhir sebelum intervensi berakhir. Jumlah konsumsi energi yang diukur dengan metode recall $2 \times 24$ jam tidak berurutan dinyatakan dalam satuan kcal dan diolah dengan menggunakan nutrisurvey (14). Data episode penyakit infeksi dan angka kecukupan gizi di kumpulkan datanya oleh enumerator penelitian yaitu perawat puskesmas penanggung jawab home care dan petugas gizi di puskesmas saat melakukan home visit.

Pemberian intervensi home visit dilakukan dengan mengikuti tahapan asuhan keperawatan mulai dari tahap pengkajian sampai dengan evaluasi. Pada tahap pengkajian, perawat mengumpulkan data dasar yang meliputi data balita, konsumsi makanan balita, episode penyakit pada balita, penilaian cara pemberian anak dan pemeriksaan status gizi. Pengumpulan data dasar dilakukan oleh perawat puskesmas yang melakukan home visit dengan bantuan kader setempat. Tahap perencanaan dilakukan dengan cara mengidentifikasi masalah keperawatan yang muncul pada balita malnutrisi. Pada tahap perencanaan, perawat menyusun rencana asuhan keperawatan yang disesuaikan dengan permasalahan klien saat pengkajian. Perawat yang memberikan home visit dibekali dengan buku pedoman asuhan keperawatan untuk keluarga balita malnutrisi yang disusun dengan mengacu pada Herdman, 2010; Johnson, 2000; James, 2007; McCloskey, 1996; Haryanti, 2010; Panduan MTBS dalam DepKes 2008 (15-19).

Tahap intervensi adalah serangkaian tindakan tentang cara memberi makan, cara mengasuh, cara merawat, cara menilai pertumbuhan dan perkembangan anak yang dilakukan oleh perawat kepada ibu atau pengasuh anak dalam bentuk kunjungan rumah (home visit). Sesi intervensi dilakukan dalam 3 tahap yaitu tahap pendampingan intensif, tahap pendampingan penguatan dan tahap mandiri. Pada tahap pendampingan intensif, balita dikunjungi seminggu dua kali selama satu bulan. Tahap pendampingan penguatan, perawat melakukan kunjungan dua minggu sekali selama satu bulan. Tahap pendampingan mandiri, keluarga hanya dikunjungi satu bulan sekali. Total kunjungan pada setiap balita adalah 7 kali kunjungan. Tahap terakhir dari asuhan keperawatan adalah tahap evaluasi hasil. Output yang dinilai pada akhir sesi ini adalah penilaian kembali asupan nutrisi, dan frekuensi mengalami penyakit infeksi. Perawat puskesmas yang melakukan home visit dibekali dengan logbook untuk setiap balita. Satu orang perawat puskesmas maksimal memberikan asuhan pada 3 balita malnutrisi akut berat.

\section{HASIL DAN BAHASAN}

\section{Karakteristik Balita}

Balita yang mengikuti penelitian adalah 56 orang balita dengan malnutrisi akut berat berusia 6-60 bulan. Kelompok intervensi berjumlah 33 orang dan kelompok kontrol berjumlah 23 orang. Karakteristik balita berdasarkan episode penyakit infeksi dan angka kecukupan gizi dapat dilihat pada Tabel 1 dan Tabel 2.

Berdasarkan Tabel 1, distribusi karakteristik balita yang lebih besar berresiko menderita penyakit infeksi adalah pada karakteristik jumlah balita dalam keluarga satu orang, jenis kelamin perempuan, riwayat ASI tidak eksklusif, usia ibu $<35$ tahun, penghasilan orang tua $<U M R$, pendidikan ibu rendah namun pendidikan ayah tinggi, serta ibu sebagai pengasuh balita di rumah. Hasil uji beda memperlihatkan karakteristik jenis kelamin, dan penghasilan orang tua memiliki karakteristik 
yang berbeda antara kelompok intervensi dengan kelompok kontrol.

Berdasarkan Tabel 2, distribusi karakteristik balita yang angka kecukupan gizinya lebih rendah dari standar adalah pada karakteristik jumlah balita dalam keluarga lebih dari satu orang, jenis kelamin laki-laki, riwayat ASI eksklusif, usia ibu $<35$ tahun, penghasilan orang tua $\geq U M R$, pendidikan ibu dan ayah rendah, serta pengasuh balita di rumah bukan ibu. Hasil uji beda memperlihatkan tidak ada beda pada semua karakteristik antara kelompok intervensi dengan kelompok kontrol.

\section{Pengaruh Home Visit terhadap Penurunan Episode Penyakit Infeksi}

Intervensi home visit pada balita malnutrisi akut berat dapat menurunkan episode penyakit infeksi dengan nilai $p=0,003$. Perubahan jumlah hari sakit sebelum dan sesudah intervensi dapat dilihat pada Tabel 3.
Berdasakan pada Tabel 3 terlihat sebelum intervensi home visit setelah dibandingkan antara kelompok intervensi dan kelompok kontrol, tidak terlihat adanya penurunan yang signifkan dengan nilai $p$-value 0,59 , sedangkan setelah intervensi terlihat penurunan yang signifikan dengan $p$-value 0,003 . Pada Tabel 3 terlihat rerata hari sakit sebelum intervensi pada kelompok intervensi adalah 2,64 hari dan pada akhir intervensi menurun menjadi 0,21 hari. Pada kelompok kontrol juga mengalami penurunan dari sebelum intervensi rerata 3,09 hari dan setelah intervensi menjadi 1,70 hari. Hasil analisis menunjukkan intervensi home visit selama 3 bulan dapat menurunkan angka kejadian infeksi pada balita malnutrisi akut berat.

Pada awal sebelum pemberian intervensi, tidak terlihat adanya penurunan episode penyakit infeksi dikarenakan balita belum diberikan intervensi home visit, dimana pada saat home visit, perawat mengajarkan terkait pentingnya dan teknik cuci tangan

Tabel 1. Distribusi Karakteristik Balita Berdasarkan Episode Penyakit Infeksi pada Balita Manutrisi Akut Berat di Yogyakarta

\begin{tabular}{|c|c|c|c|c|c|c|c|c|}
\hline \multirow[b]{2}{*}{ Karakteristik dan Kategori } & \multicolumn{2}{|c|}{$\begin{array}{c}\text { Kelompok Intervensi } \\
(n=33)\end{array}$} & \multicolumn{2}{|c|}{$\begin{array}{c}\text { Kelompok Kontrol } \\
(n=23)\end{array}$} & \multicolumn{2}{|c|}{$\begin{array}{c}\text { Total } \\
(\mathrm{N}=56)\end{array}$} & \multirow[b]{2}{*}{ OR } & \multirow[b]{2}{*}{$p$} \\
\hline & $\begin{array}{c}\text { Pernah } \\
(n, \%)\end{array}$ & $\begin{array}{c}\text { Tidak } \\
\text { Pernah } \\
(\mathrm{n}, \%)\end{array}$ & $\begin{array}{c}\text { Pernah } \\
(n, \%)\end{array}$ & $\begin{array}{c}\text { Tidak } \\
\text { Pernah } \\
(n, \%)\end{array}$ & $\begin{array}{c}\text { Pernah } \\
(n, \%)\end{array}$ & $\begin{array}{c}\text { Tidak } \\
\text { Pernah } \\
(\mathbf{n}, \%) \\
\end{array}$ & & \\
\hline \multicolumn{9}{|l|}{ Jumlah Balita dalam } \\
\hline Keluarga & $13(59,1)$ & $9(40,9)$ & $10(83,3)$ & $2(16,7)$ & $23(67,6)$ & $11(32,4)$ & 0,48 & 0,18 \\
\hline $\begin{array}{l}1 \text { orang } \\
\text { Lebih dari } 1 \text { orang }\end{array}$ & $5(45,5)$ & $6(54,5)$ & $6(54,5)$ & $5(45,5)$ & $11(50,0)$ & $11(50,0)$ & & \\
\hline Jenis Kelamin & $9(45,0)$ & $11(55,0)$ & $7(53,8)$ & $6(46,2)$ & $16(48,5)$ & $17(51,5)$ & 5,04 & 0,02 \\
\hline $\begin{array}{l}\text { Laki-laki } \\
\text { Perempuan }\end{array}$ & $9(69,2)$ & $4(30,8)$ & $9(90,0)$ & $1(10,0)$ & $18(78,3)$ & $5(21,7)$ & & \\
\hline Riwayat ASI Eksklusif & $9(64,3)$ & $5(35,7)$ & $5(62,5)$ & $3(37,5)$ & $14(63,6)$ & $8(36,4)$ & 0,82 & 0,72 \\
\hline $\begin{array}{l}\text { Eksklusif } \\
\text { Tidak Eksklusif }\end{array}$ & $9(47,4)$ & $10(52,6)$ & $11(73,3)$ & $4(26,7)$ & $20(58,8)$ & $14(41,2)$ & & \\
\hline Usia ibu & $13(65,0)$ & $7(35,0)$ & $14(93,3)$ & $1(6,7)$ & $23(65,7)$ & $12(34,3)$ & 0,57 & 0,32 \\
\hline $\begin{array}{l}<35 \text { tahun } \\
\geq 35 \text { tahun }\end{array}$ & $5(38,5)$ & $8(61,5)$ & $7(87,5)$ & $1(12,5)$ & $11(52,4)$ & $10(47,6)$ & & \\
\hline Penghasilan Orang Tua & $7(41,2)$ & $10(58,8)$ & $4(66,7)$ & $2(33,3)$ & $11(47,8)$ & $12(52,2)$ & 2,51 & 0,09 \\
\hline $\begin{array}{l}\geq \text { UMR } \\
<\text { UMR }\end{array}$ & $11(68,8)$ & $5(31,3)$ & $12(70,6)$ & $5(29,4)$ & $23(69,7)$ & $10(30,3)$ & & \\
\hline Tingkat Pendidikan Ibu & $13(54,2)$ & $11(45,8)$ & $13(86,7)$ & $3(25,0)$ & $22(61,1)$ & $(14(38,9)$ & 0,96 & 0,94 \\
\hline $\begin{array}{l}\text { Tinggi } \\
\text { Rendah }\end{array}$ & $5(55,6)$ & $4(44,4)$ & $8(100)$ & $4(36,4)$ & $12(60,0)$ & $8(40,0)$ & & \\
\hline Tingkat Pendidikan Ayah & $14(56,0)$ & $11(44,0)$ & $12(80,0)$ & $3(20,0)$ & $26(65,0)$ & $14(35,0)$ & 0,54 & 0,30 \\
\hline $\begin{array}{l}\text { Tinggi } \\
\text { Rendah }\end{array}$ & $4(50,0)$ & $4(50,0)$ & $4(50,0)$ & $4(50,0)$ & $8(50,0)$ & $8(50,0)$ & & \\
\hline Pengasuh Balita di Rumah & $15(57,7)$ & $11(42,3)$ & $14(70,0)$ & $6(30,0)$ & $29(63,0)$ & $17(37,0)$ & 0,59 & 0,44 \\
\hline $\begin{array}{l}\text { Ibu } \\
\text { Bukan Ibu }\end{array}$ & $3(42,9)$ & $4(57,1)$ & $2(66,7)$ & $1(33,3)$ & $5(50,0)$ & $5(50,0)$ & & \\
\hline
\end{tabular}

Catatan:

Pernah: pernah menderita penyakit infeksi

Tidak pernah: tidak pernah menderita penyakit infeksi 
Tabel 2. Distribusi Karakteristik Balita Berdasarkan Angka Kecukupan Gizi pada Balita Malnutrisi Akut Berat di Yogyakarta

\begin{tabular}{|c|c|c|c|c|c|c|c|c|}
\hline \multirow{2}{*}{ Karakteristik dan Kategori } & \multicolumn{2}{|c|}{$\begin{array}{l}\text { Kelompok Intervensi } \\
\qquad(n=33)\end{array}$} & \multicolumn{2}{|c|}{$\begin{array}{l}\text { Kelompok Kontrol } \\
(n=23)\end{array}$} & \multicolumn{2}{|c|}{$\begin{array}{l}\text { Total } \\
(n=56)\end{array}$} & \multirow{2}{*}{ OR } & \multirow{2}{*}{$\boldsymbol{p}^{*}$} \\
\hline & $\begin{array}{l}\text { Kurang } \\
(\mathrm{n}, \%)\end{array}$ & $\begin{array}{l}\text { Sesuai } \\
(n, \%)\end{array}$ & $\begin{array}{l}\text { Kurang } \\
(\mathrm{n}, \%)\end{array}$ & $\begin{array}{c}\text { Sesuai } \\
(n, \%)\end{array}$ & $\begin{array}{l}\text { Kurang } \\
(\mathrm{n}, \%)\end{array}$ & $\begin{array}{c}\text { Sesuai } \\
(n, \%)\end{array}$ & & \\
\hline \multicolumn{9}{|l|}{ Jumlah Balita dalam Keluarga } \\
\hline 1 orang & $18(81,8)$ & $4(18,2)$ & $11(91,7)$ & $1(8,3)$ & $29(85,3)$ & $5(14,7)$ & 3,62 & 0,23 \\
\hline Lebih dari 1 orang & $11(100)$ & $0(0)$ & $10(90,9)$ & $1(9,1)$ & $21(95,5)$ & $1(4,5)$ & & \\
\hline \multicolumn{9}{|l|}{ Jenis Kelamin } \\
\hline Laki-laki & $18(90,0)$ & $2(10,0)$ & $12(92,3)$ & $1(7,7)$ & $30(90,9)$ & $3(9,1)$ & 0,67 & 0,48 \\
\hline Perempuan & $11(84,6)$ & $2(15,4)$ & $9(90,0)$ & $1(10,0)$ & $20(87,0)$ & $3(13,0)$ & & \\
\hline \multicolumn{9}{|l|}{ Riwayat ASI Eksklusif } \\
\hline Eksklusif & $13(92,9)$ & $1(7,1)$ & $8(100)$ & $0(0)$ & $21(95,5)$ & $1(4,5)$ & 0,28 & 0,23 \\
\hline Tidak Eksklusif & $16(84,2)$ & $3(15,8)$ & $13(86,7)$ & $2(13,3)$ & $29(85,3)$ & $5(14,7)$ & & \\
\hline \multicolumn{9}{|l|}{ Usia Ibu } \\
\hline$<35$ tahun & $18(90,0)$ & $2(10,0)$ & $10(66,7)$ & $5(33,3)$ & $32(91,4)$ & $3(8,6)$ & 0,56 & 0,40 \\
\hline$\geq 35$ tahun & $11(84,6)$ & $2(15,4)$ & $6(75,0)$ & $2(25,0)$ & $18(85,7)$ & $3(14,3)$ & & \\
\hline \multicolumn{9}{|l|}{ Penghasilan Orangtua } \\
\hline$\geq$ UMR & $15(88,2)$ & $2(11,8)$ & $6(100)$ & $0(0)$ & $21(91,3)$ & $2(8,7)$ & 0,69 & 0,52 \\
\hline$<$ UMR & $14(87,5)$ & $2(12,5)$ & $15(88,2)$ & $2(11,8)$ & $29(87,9)$ & $4(12,1)$ & & \\
\hline \multicolumn{9}{|l|}{ Tingkat Pendidikan Ibu } \\
\hline Tinggi & $20(83,3)$ & $4(16,7)$ & $11(91,7)$ & $1(8,3)$ & $31(86,1)$ & $5(13,9)$ & 3,06 & 0,41 \\
\hline Rendah & $9(100)$ & $0(0)$ & $10(90,9)$ & $1(9,1)$ & $19(95,0)$ & $1(5,0)$ & & \\
\hline \multicolumn{9}{|l|}{ Tingkat Pendidikan Ayah } \\
\hline Tinggi & $21(84,0)$ & $4(16,0)$ & $13(86,7)$ & $2(13,3)$ & $34(85,0)$ & $6(15,0)$ & 1,12 & 0,12 \\
\hline Rendah & $8(100)$ & $0(0)$ & $8(100)$ & $0(0)$ & $16(100)$ & $0(0)$ & & \\
\hline \multicolumn{9}{|l|}{ Pengasuh Balita di Rumah } \\
\hline lbu & $23(88,5)$ & $3(11,5)$ & $18(90,0)$ & $2(10,0)$ & $41(89,3)$ & $5(10,9)$ & 1,09 & 0,71 \\
\hline Bukan Ibu & $6(85,7)$ & $1(14,3)$ & $3(100)$ & $0(0)$ & $9(90,0)$ & $1(10,0)$ & & \\
\hline
\end{tabular}

Catatan:

Kurang: Angka kecukupan gizi lebih rendah dari nilai standar sesuai usia balita

Sesuai: Angka kecukupan gizi sesuai atau lebih dari nilai standar sesuai usia balita

" $p<0,05$ based on Fisher Exact Test

Tabel 3. Episode Penyakit Infeksi pada Malnutrisi Balita Sebelum dan Setelah Intervensi pada Kelompok Intervensi dan Kelompok Kontrol di Yogyakarta

\begin{tabular}{|c|c|c|c|c|}
\hline \multirow[t]{2}{*}{$\begin{array}{l}\text { Episode Penyakit Infeksi } \\
\text { (hari) }\end{array}$} & $\begin{array}{c}\text { Kelompok } \\
\text { Intervensi } \\
(n=33)\end{array}$ & $\begin{array}{c}\text { Kelompok } \\
\text { Kontrol } \\
(n=23)\end{array}$ & $\begin{array}{l}\text { Mean Difference } \\
(95 \% \mathrm{Cl})\end{array}$ & $p$ \\
\hline & Mean士SD & Mean士SD & & \\
\hline $\begin{array}{l}\text { Sebelum: Dua minggu pada } \\
\text { awal intervensi }\end{array}$ & $2,64 \pm 3,29$ & $3,09 \pm 2,80$ & $-0,45(-2,14 ; 1,24)$ & 0,59 \\
\hline $\begin{array}{l}\text { Sesudah: Dua minggu sebelum } \\
\text { intervensi berakhir }\end{array}$ & $0,21 \pm 0,70$ & $1,70 \pm 2,12$ & $-1,48(-2,43 ;-0,54)$ & 0,003 \\
\hline
\end{tabular}

yang benar. Kejadian diare sangat berkaitan erat dengan perilaku individu dalam menjaga kebersihan. Intervensi home visit memberikan dampak yang signifikan dikarenakan pada saat home visit, perawat mengajarkan bagaimana cara menjaga kebersihan lingkungan diantaranya adalah cara mencuci tangan yang benar dan menjaga kebersihan makanan. Tangan dan makanan yang bersih akan meminimalisir jumlah bakteri sehingga anak tidak mudah terkena penyekit infeksi seperti diare. Penyebab kejadian penyakit infeksi pada balita ini mempunyai hubungan yang signifikan dengan malnutrisi, sehingga apabila episode penyakit infeksi dapat diatasi maka status gizi balita akan dapat diperbaiki (13).

Menurut Irena, intervensi pada tingkat komunitas dapat diperkuat untuk mencegah peningkatan kejadian diare pada balita malnutrisi. Intervensi tersebut meliputi edukasi cuci tangan, pemberian suplemen zinc, rehidrasi oral dan intervensi terkait sanitasi dan air bersih. Pada saat penerapan program pemberian asuhan berbasis komunitas pada balita malnutrisi, angka kejadian diare dapat diturunkan sekitar 5\% (20). Hasil penelitian Yebyo, menunjukkan bahwa balita malnutrisi yang tidak mengalami diare 
selama intervensi, mempunyai peluang 2,2 kali lebih besar sembuh dari malnutrisi dibandingkan dengan balita yang mengalami diare selama dirawat di pusat pemulihan gizi (21).

Kejadian penyakit infeksi yang sering diderita balita malnutrisi adalah diare, ISPA, dan infeksi saluran kemih (ISK). Hal ini sesuai dengan pernyataan penelitian sebelumnya bahwa kejadian infeksi yang sering terjadi pada balita malnutrisi adalah infeksi saluran pernafasan dan penyakit infeksi sistem gastrointestinal $(22,23)$. Penyakit infeksi saluran pernafasan dan diare merupakan dua penyebab utama kesakitan dan kematian pada balita malnutrisi di negara berkembang. Penyakit infeksi berkaitan dengan tingginya kejadian penyakit menular dan buruknya kesehatan lingkungan.

Penyakit infeksi dan kejadian malnutrisi saling berkaitan satu dengan yang lainnya dan saling memperberat masing-masing kondisi. Penyakit infeksi merupakan penyebab langsung kejadian malnutrisi dan sebaliknya kejadian malnutrisi memberikan dampak buruk terhadap imunitas tubuh balita sehingga mudah terserang penyakit infeksi $(13,24)$. Beberapa penelitian menemukan hubungan antara malnutrisi, rendahnya imunitas seluler, dengan insiden kejadian penyakit infeksi gastrointestinal atau infeksi sistem respirasi pada usia balita.

Terdapat berbagai mekanisme hubungan kejadian malnutrisi dengan penyakit infeksi. Malnutrisi merusak perkembangan sistem imun normal. Stimulasi respon imun oleh infeksi meningkatkan kebutuhan metabolisme tubuh. Infeksi sendiri dapat menyebabkan hilangnya penyimpanan zat penting dalam tubuh seperti protein, energi, mineral dan vitamin. Selama respon imun, kebutuhan energi meningkat dan di waktu yang sama individu yang menderita penyakit infeksi mengalami penurunan asupan nutrisi. Respon metabolik terhadap infeksi meliputi hipermetabolisme, keseimbangan nitrogen negatif, peningkatan glukoneogenesis dan peningkatan oksidasi lemak (13).

Malnutrisi dan infeksi dapat dilihat dari dua aspek dimana malnutrisi menyebabkan penurunan daya tahan tubuh seseorang dan infeksi menyebabkan malnutrisi melalui patogenesis penyakit. Hubungan malnutrisi dengan penyakit infeksi juga dapat dilihat secara level mikro dan makro. Pada level mikro yaitu dari sisi individu, dimana tingkat imunitas seseorang dipengaruhi oleh asupan makronutrien dan mikronutrien yang optimal sehingga terjadi malnutrisi dan menurunkan respon imun $(12,13)$. Malnutrisi dan penyakit infeksi merupakan hubungan saling mempengaruhi secara langsung (bidirectional), dimana malnutrisi dapat menyebabkan penyakit infeksi dan infeksi dapat mengganggu metabolisme zat gizi sehingga menyebabkan malnutrisi (12).

Pada tingkat individu, kekurangan kalori dan protein mempengaruhi kemampuan tubuh untuk memproduksi komponen sistem imun yang dibutuhkan untuk melawan infeksi dan memperbaiki sel-sel yang rusak. Pada malnutrisi karena kekurangan kalori dan protein biasanya terjadi penurunan secara signifikan pada sel-sel imun, fungsi fagosit, sistem komplemen, sekresi imunoglobulin A dan produksi sitokinin (13). Kekurangan salahsatu zat mikronutrien juga dapat mengganggu respon imun seseorang. Zat-zat mikronutrien yang sangat mempengaruhi respon imun meliputi zinc, selenium, zat besi, vitamin $A$, vitamin C, vitamin B-6, dan asam folat (12). Beberapa penelitian menyebutkan bahwa diare merupakan penyakit infeksi yang paling banyak diderita oleh balita malnutrisi, kemudian diikuti oleh infeksi saluran pernafasan $(25,26)$.

\section{Pengaruh Home Visit terhadap Peningkatan Angka Kecukupan Gizi}

Hasil penelitian menunjukkan program home visit dapat meningkatkan asupan nutrisi balita pada kelompok intervensi. Pengukuran asupan makanan dengan menggunakan food recall 24 jam dimana peneliti menanyakan pada ibu berapa kali anak makan dan komposisi makanan serta bahan-bahan yang digunakan. Untuk meningkatkan akurasi, ukuran porsi makanan menggunakan ukuran rumah tangga seperti satu sendok makan, satu piring, satu gelas dan sebagainya.

Berdasarkan pada Tabel 4 terlihat persentase angka kecukupan gizi sebelum intervensi pada kelompok intervensi adalah $83,65 \%$ dan pada akhir intervensi meningkat menjadi 106,23\%. Pada kelompok kontrol juga mengalami peningkatan dari sebelum intervensi rerata $73,84 \%$ dan setelah intervensi menjadi $85,22 \%$. Hasil analisis menunjukkan sebelum intervensi home visit tidak terdapat peningkatan yang signifikan dengan $p$-value 0,28 sedangkan setelah intervensi terdapat peningkatan dengan $p$-value 0,03 sehingga dapat disimpulkan bahwa intervsni home visit dapat meningkatkan persentase angka kecukupan gizi balita malnutrisi akut berat. 
Tabel 4. Persentase Angka Kecukupan Energi pada Balita Malnutrisi Sebelum dan Setelah Intervensi pada Kelompok Intervensi dan Kontrol di Yogyakarta

\begin{tabular}{|c|c|c|c|c|}
\hline \multirow[t]{2}{*}{ Angka Kecukupan Energi (\%) } & $\begin{array}{l}\text { Kelompok Intervensi } \\
(n=33)\end{array}$ & $\begin{array}{l}\text { Kelompok Kontrol } \\
(n=23)\end{array}$ & \multirow[t]{2}{*}{$\begin{array}{c}\text { Mean Difference } \\
(95 \% \mathrm{Cl})\end{array}$} & \multirow[t]{2}{*}{$p$} \\
\hline & Mean士SD & Mean士SD & & \\
\hline $\begin{array}{l}\text { Sebelum: Persentase rata-rata angka } \\
\text { kecukupan energi pada dua hari pada } \\
\text { awal intervensi }\end{array}$ & $83,65 \pm 40,35$ & $73,84 \pm 16,19$ & $9,81(-8,02,27,83)$ & 0,28 \\
\hline $\begin{array}{l}\text { Sesudah: Persentase rata-rata angka } \\
\text { kecukupan energi pada dua hari } \\
\text { sebelum intervensi berakhir }\end{array}$ & $106,23 \pm 38,64$ & $85,22 \pm 30,18$ & $21,01(1,71,40,31)$ & 0,03 \\
\hline
\end{tabular}

Hasil penelitian menunjukkan terjadi peningkatan persentase angka kecukupan gizi setelah diberikan intervensi home visit selama 3 bulan. Faktor penyebab langsung malnutrisi adalah konsumsi makanan yang tidak memenuhi jumlah dan komposisi zat gizi yang memenuhi syarat makanan beragam, bergizi seimbang, dan aman. Asupan makanan yang tidak adekuat dapat berkontribusi pada tingginya angka malnutrisi pada balita (11).

Pada saat melakukan home visit, perawat mengajarkan cara pemberian makan yang baik pada balita. Praktek pemberian makanan yang tidak sesuai pada bayi dan balita berkontribusi dalam peningkatan angka kejadian malnutrisi di negara berkembang (5). Praktek pemberian makanan yang optimal harus dimulai sejak dini (dalam satu jam setelah melahirkan), merupakan cara yang dapat menurunkan paparan terhadap penyakit dan meningkatkan sistem imun anak. Manfaat lain dari inisiasi menyusui dini adalah menurunkan angka kematian bayi, adanya kontak kulit antara ibu dan anak, mempersiapkan saluran cerna dengan lebih baik, mencegah terjadinya hipotermia, dan meningkatkan kemampuan untuk memberikan ASI eksklusif (5). Hasil penelitian Vir yang melakukan intervensi home visit menunjukkan terjadi peningkatan pemberian ASI sedini mungkin (inisiasi menyusui dini) meningkat dari 4,6\% menjadi $21,9 \%$, pemberian kolostrum meningkat dari $27,9 \%$ menjadi $52,9 \%$ dan pengenalan makanan tambahan yang sehat pada anak usia 6-9 bulan meningkat dari $18,2 \%$ menjadi $62,6 \%(27)$.

Manajemen malnutrisi akut berat berdasarkan WHO adalah perawatan individu, rehabilitasi nutrisi, rawat inap dan konseling keluarga (28). Berdasarkan pedoman penatalaksanaan balita malnutrisi dari $\mathrm{WHO}$ (1999), maka balita yang dapat dirawat di rumah adalah balita yang sudah memasuki fase rehabilitasi. Prinsip manajemen pada fase rehabilitasi adalah untuk mendorong anak makan sebanyak mungkin, memulai kembali dan atau mendorong pemberian
ASI, menstimulasi perkembangan fisik dan emosional anak dan mempersiapkan ibu untuk merawat anaknya di rumah (29).

\section{SIMPULAN DAN SARAN}

Program home visit yang dilakukan selama 3 bulan dengan menggunakan pendekatan asuhan keperawatan dapat menurunkan angka kejadian infeksi dan meningkatkan prosentase angka kecukupan gizi pada balita malnutrisi akut berat di Yogyakarta. Hasil diatas menunjukkan bahwa program home visit dengan pendekatan 3 fase kunjungan dengan minimal kunjungan 7 kali dapat menjadi salahsatu kebijakan yang dapat dipertimbangkan khususnya oleh Pemerintah Kota Yogyakarta sebagai salah satu pendekatan untuk menangani permasalahan yang berkaitan dengan kejadian malnutrisi pada balita. Terdapat beberapa saran yang penulis tujukan kepada Dinas Kesehatan Yogyakarta yaitu melakukan pelatihan secara berkala kepada para perawat puskesmas terkait konsep pemberian asuhan pada berbagai kelompok usia dan permasalahannya, menyediakan form dokumentasi asuhan keperawatan yang efektif dan efisien agar perawat puskesmas pada saat menjalankan tugas perkesmas dapat mengisi form dokumentasi keperawatan dengan mudah dan perlunya kerjasama dalam melaksanakan program home visit, karena program ini adalah interdisiplin, tidak hanya dilakukan oleh perawat.

\section{RUJUKAN}

1. Bhutta ZA, Das JK, Rizvi A, Gaffey MF, Walker $\mathrm{N}$, Horton $\mathrm{S}$, et al. Evidence-based interventions for improvement of maternal and child nutrition: what can be done and at what cost? Lancet [Internet]. 2013 Aug;382(9890):452-77. Available from: http://linkinghub.elsevier.com/retrieve/pii/ S0140673613609964. 
2. Black RE, Allen LH, Bhutta ZA, Caulfield LE, de Onis M, Ezzati M, et al. Maternal and child undernutrition: global and regional exposures and health consequences. Lancet (London, England) [Internet]. 2008 Jan 19;371(9608):243-60. Available from: http://www.ncbi.nlm.nih.gov/ pubmed/18207566.

3. Schoonees A, Lombard M, Musekiwa A, Nel E, Volmink J. Ready-to-use therapeutic food for homebased treatment of severe acute malnutrition in children from six months to five years of age. In: Volmink J, editor. Cochrane Database of Systematic Reviews [Internet]. Chichester, UK: John Wiley \& Sons, Ltd; 2013. Available from: http://doi.wiley. com/10.1002/14651858.CD009000.pub2.

4. UNICEF. The big picture [Internet]. 2011 [cited 2012 Jan 5]. Available from: https://www.unicef. org/nutrition/index_bigpicture.html.

5. Roche ML. A community-based positive deviance/hearth intervention to improve infant and young child nutrition in the Ecuadorian Andes [Internet]. McGill University; 2011 [cited 2017 Mar 23]. Available from: http://digitool. library.mcgill.ca/webclient/StreamGate?folder id $=0$ \&dvs $=1490240761575 \sim 684$.

6. Kementerian Kesehatan Republik Indonesia. Profil kesehatan Indonesia Tahun 2011. Jakarta: Kementrian Kesehatan RI; 2012.

7. Puett $\mathrm{C}$. Community case management of acute malnutrition by community health workers in southern Bangladesh: Examining quality of care and cost-effectiveness [Internet]. Tufts University; 2011. Available from: http://pqdtopen.proquest. com/doc/911029633.html?FMT=ABS.

8. Royal College of Nursing. Malnutrition - what nurses working with children and young people need to know and do [Internet]. London; 2006 [cited 2017 Mar 23]. Available from: https://www2. rcn.org.uk/_data/assets/pdf_file/0006/65499/ malnutrition.pdf.

9. Correa B, Leandro Merhi VA, Pagotto Fogaca K, Marques de Oliveira MR. Caregiver's education level, not income, as determining factor of dietary intake and nutritional status of individuals cared for at home. J Nutr Health Aging [Internet]. 2009 Aug;13(7):609-14. Available from: http://www. ncbi.nlm.nih.gov/pubmed/19621196.

10. Goudet SM, Faiz S, Bogin BA, Griffiths PL. Pregnant women's and community health workers' perceptions of root causes of malnutrition among infants and young children in the slums of Dhaka, Bangladesh. Am J Public Health [Internet]. 2011 Jul;101(7):1225-33. Available from: http://www. ncbi.nlm.nih.gov/pubmed/21653248.

11. Vazir S, Engle P, Balakrishna N, Griffiths PL, Johnson SL, Creed-Kanashiro H, et al. Clusterrandomized trial on complementary and responsive feeding education to caregivers found improved dietary intake, growth and development among rural Indian toddlers. Matern Child Nutr [Internet]. 2013 Jan;9(1):99-117. Available from: http://doi. wiley.com/10.1111/j.1740-8709.2012.00413.x.

12. Ostrach B, Singer M. Syndemics of War: Malnutrition-Infectious Disease Interactions and The Unintended Health Consequences of Intentional War Policies. Ann Anthropol Pract [Internet]. $2012 \mathrm{Nov} ; 36(2): 257-73$. Available from: http://doi.wiley.com/10.1111/napa.12003.

13. Rodríguez L, Cervantes E, Ortiz R. Malnutrition and gastrointestinal and respiratory infections in children: a public health problem. Int J Environ Res Public Health [Internet]. 2011 Apr;8(4):1174205. Available from: http://www.ncbi.nlm.nih.gov/ pubmed/21695035.

14. Erhardt J, Gross R. Nutrisurvey. 2007.

15. Herdman HT. Diagnosis keperawatan: Definisi dan klasifikasi 2009-2011. Jakarta: EGC; 2010.

16. Johnson M. Nursing Outcomes Classification (NOC). 2nd ed. Missouri: Mosby Inc. St.Louis; 2000.

17. James A. Nursing care of children: Principles and practice. 3rd ed. Canada: Saunders Elsevier; 2007.

18. Haryanti F. Upaya peningkatan mutu pelayanan keperawatan anak melalui pelatihan Manajemen Terpadu Balita Sakit (MTBS) pada tatanan rumah sakit Di RS Cut Nyak Dhien Meulaboh Pasca Bencana. Universitas Gadjah Mada; 2010.

19. Depkes RI. Buku bagan Manajemen Terpadu Balita Sakit (MTBS). Jakarta; 2008.

20. Irena AH, Mwambazi M, Mulenga V. Diarrhea is a Major killer of Children with Severe Acute Malnutrition Admitted to Inpatient Set-up in Lusaka, Zambia. Nutr J [Internet]. 2011 Dec 11;10(1):110. Available from: http://nutritionj.biomedcentral.com/ articles/10.1186/1475-2891-10-110.

21. Yebyo HG, Kendall C, Nigusse D, Lemma W. Outpatient Therapeutic Feeding Program Outcomes and Determinants in Treatment of Severe Acute Malnutrition in Tigray, Northern 
Ethiopia: A Retrospective Cohort Study. Bhutta ZA, editor. PLoS One [Internet]. 2013 Jun 6;8(6):e65840. Available from: http://dx.plos. org/10.1371/journal.pone.0065840.

22. Sarkar $R$, Sivarathinaswamy $P$, Thangaraj $B$, Sindhu KNC, Ajjampur SSR, Muliyil J, et al. Burden of childhood diseases and malnutrition in a semi-urban slum in southern India. BMC Public Health [Internet]. 2013 Jan 30;13:87. Available from: http://www.ncbi.nlm.nih.gov/ pubmed/23360429.

23. Das S, Rahman RM. Application of ordinal logistic regression analysis in determining risk factors of child malnutrition in Bangladesh. Nutr J [Internet]. 2011 Dec 14;10(1):124. Available from: http://nutritionj.biomedcentral.com/ articles/10.1186/1475-2891-10-124.

24. Nency Y, Arifin M. Gizi Buruk, Ancaman Generasi yang Hilang. Inov Online. 2005;5(17).

25. Page A-L, de Rekeneire N, Sayadi S, Aberrane $S$, Janssens $A-C$, Rieux $C$, et al. Infections in Children Admitted with Complicated Severe Acute Malnutrition in Niger. von Seidlein L, editor. PLoS One [Internet]. 2013 Jul 17;8(7):e68699. Available from: http://dx.plos.org/10.1371/journal. pone.0068699.
26. Irshad M, Hayat M, Ahmad A, Khalil B, Hussain M. Case Fatality Rate and Etiological Factors of Malnutrition In Children Less Than 5 Years of Age. J Postgrad Med Inst (Peshawar - Pakistan) [Internet]. 2014 [cited 2017 Mar 23];28(1). Available from: http://www.jpmi.org.pk/index.php/ jpmi/article/view/1485.

27. Vir S. Community based maternal and child health nutrition project, Uttar Pradesh: An innovative strategy focusing on "at risk" families. Indian J Community Med [Internet]. 2013;38(4):234. Available from: http://www.ijcm.org.in/text. asp?2013/38/4/234/120159.

28. Shafiq Y, SaleemA, Lassi ZS, ZaidiAK. Communitybased versus health facility-based management of acute malnutrition for reducing the prevalence of severe acute malnutrition in children 6 to 59 months of age in low- and middle-income countries. In: Shafiq Y, editor. Cochrane Database of Systematic Reviews [Internet]. Chichester, UK: John Wiley \& Sons, Ltd; 2016. Available from: http://doi.wiley.com/10.1002/14651858. CD010547.pub2.

29. World Health Organization. Management of Severe Malnutrition: A Manual For Physicians and Other Senior Health Workers. 1999. 